\title{
부산 개발원조총회(HLF4)와 세계시민사회의 대응전략 : Better Aid와 Open Forum을 중심으로
}

\author{
손 혁 상 경희대학교 국제개발협력연구센터/공공대학원 교수
}

\section{I. 들어가며}

2011년 11월 30일부터 12월 2일까지 3일간 개최되는 부산 개발원조총회(HLF 4) 본회에 OECD회 원국 대표, 개발도상국과 국제기구의 공식대표단 외에 300 명의 시민사회대표들이 공식적으로 참여 할 예정이다. 이는 지난 2008년 아크라에서 개최된 제3차 원조효과성 고위급회의(Third High Level Forum on Aid Effecitveness, HLF3)에서 80명의 시민사회대표가 본회의에 등록하고 참가한 것에 비해 시민사회의 참여가 비약적으로 확대되었음을 보여준다.

2008년 가나 아크라에서 개최된 HLF3에서는 그동안 꾸준히 논의되었던 개발협력에서 시민사회의 중요성이 공식적으로 인정되는 계기가 되었다. HLF3에서 발표한 아크라행동계획(Accra Action Agenda, AAA)에서는 CSO가 독립적인 주요 개발주체로 인정되었다. 또한, 개발에 대한 $\mathrm{CSO}$ 의 기여 를 극대화 할 수 있는 법적·제도적 환경조성에 협력할 것을 합의하였다. 개발원조 정책의 최종 소비 자이자 공급자가 되는 시민사회가 국제개발원조에 있어 독립적인 권리를 지닌 자율적 행위자로 인식 된 것이다.

정부와 국제기구의 시민사회단체에 대한 독립적 개발주체로서의 인정과 상호 파트너십의 확대는 무엇보다도 빈곤퇴치와 개발협력분야에서 개발NGO와 시민사회단체가 보여준 성과가 공여국정부나 다른 개발주체가 시민사회를 보는 시각의 변화에 기인한다고 볼 수 있다. 또한 개발협력분야의 재원 규모에서 $\mathrm{NGO}$ 의 기여도가 급격한 성장을 보이고 있다. 국제사회는 1950 년대 이후 개발 $\mathrm{NGO}$ 를 포함 
한 시민사회가 다자간 양자간 원조기구와 다른 전략적 강점 및 차별성을 가진다고 인정하며, 시민사 회와의 협력을 통한 $\mathrm{ODA}$ 집행 정책을 실시해왔다. 2008년 $\mathrm{OECD/DAC}$ 회원국들의 $\mathrm{NGO}$ 에 대한 $\mathrm{ODA}$ 지원규모는 순지출 기준 양자간 ODA의 $11.14 \%$ 이르고 있다.1) 또한 NGO자체 개발협력 자금규 모도 지속적으로 증가하였다. 1991년과 1992년 평균 9.8\%에 불과했던 ODA자금에 대비하여 2009년 에는 NGO 자체적으로 모금된 자금집행의 비율이 $18.4 \%$ 까지 증가하였다. ${ }^{2)}$

이와같은 배경에서 글로벌한 차원과 국내 차원의 CSO 정책애드보커시 활동이 강화되면서 UN을 비롯한 다양한 국제기구에서 $\mathrm{CSO}$ 의 참여는 당연하게 받아들여졌다. 전통적인 $\mathrm{CSO}$ 국제네트워크인 CIVICUS와 Social Watch, 지역개발과 서비스제공에서 개발정책 애드보커시까지 활동영역을 확대한 Oxfam과 World Vision과 같은 주요 국제NGO, 또한 풀뿌리 차원에서 공여국과 수원국 모두에서 활 동하는 개발/애드보커시NGO 모두가 개발원조의 효과성, 투명성, 책무성 제고를 위해 애드보커시활 동을 강화하고 있다. 특히 아크라회의 이후 조직된 Better Aid와 Open Forum이 국제적인 개발협력 규범과 정책기조 수립과정에 적극적으로 참여함으로써 기존의 원조효과성 담론의 성과를 평가하고 새로운 개발협력 의제를 수립하는데 기여하고 있다.

이 글은 Better Aid와 Open Forum의 정책입장과 지금까지의 활동을 중심으로 세계시민사회의 부 산 개발원조총회의 대응과정과 향후 전략을 살펴보고자 한다. 이와 함께 한국 시민사회의의 정책입 장과 대응 움직임도 논의하고자 한다.

\section{Better Aid의 활동현황과 대응전략}

\section{1. 일반현황}

2008년 9월 개최된 아크라회의(HLF-3)는 원조효과성을 포함한 국제개발협력 담론형성에 CSO가 본격적으로 참여할 수 있는 계기가 되었다. 아크라회의 대응을 준비하면서 개발원조분야에 정책옹호 활동을 해왔던 국제 $\mathrm{NGO}$ 들은 2007년 CSO네트워크를 결성하였고 이어 시민사회 국제운영그룹(Civil Society International Steering Group, ISG)을 조직하여 아크라회의에 본격적으로 대응을 시작하 였다. Reality of Aid(ROA), Concord, CCIC, Interaction, CIVICUS, Social Watch, Alliance 2015, AWID 등이 주도적으로 참여하여, 원조효과성에 대한 국제적 논의에 참여하고 시민사회 공동의 플랫 폼 형성을 목적으로 하였다. 이 ISG가 2008년 Better Aid 탄생의 모태가 되었다. ISG는 OECD/DAC

1) 2008년 OECD CRS (Credit Recording System)을 분석해 보면 순지출 기준 양자간 ODA 규모는 114,147.6백만 달러 인데 그 중 NGO지원 규모는 12,715.2백만 달러이다. 이 내용에는 DAC회원 국가들이 자국NGO 외에 국제NGO(예: International Trust Fund for Demining and Mine Victims Assistance, International Committee of the Red Cross)를 지원하는 경우도 포함되어 있다.

2) 손혁상 외. 2011.「개발효과성 제고를 위한 정부-시민사회 협력방안 연구」. 연구보고서 한국국제협력단 (출판 예정) 
원조효과성작업반에 설치된 시민사회 자문그룹(Advisory Group on Civil Society, AG-CS)에도 적 극적으로 참여하여 아크라회의 개발협력 부분에서 시민사회 위치와 역할에 대해 원조공여기관들이 공식적으로 인정하게 되는 결과를 가져오는데 기여하였다.

ISG는 2008년 1월에 초안이 발표되고 2009년 5월에 최종안으로 발간된 "원조 및 개발효과 개선 에 관한 정책문서"(Better Aid: A Civil Society Position Paper for the 2008 Accra High Level Forum on Aid Effectiveness)에서 첫째, 원조개혁을 추진하기 위해서는 원조효과성에서 개발효과성 으로 역점을 두어야 한다. 둘째, 2005년 원조효과성에 관해 파리선언에 포함되지 않은 주요 과제 즉, 투명성, 정책정합성, 국가시스템, 원조조건 및 예측성이 아크라회의에서는 본격적으로 다루어져야 하며, 동시에 민주적 오너십과 인권도 주요이슈로 포함되어야 한다. 셋째, 보다 야심찬 목표설정이 필요하다고 주장하였다.

한편, OECD DAC 시민사회 자문그룹(Advisory Group on Civil Society, AG-CS)도 ISG의 주장 에 동조하면서 $\mathrm{DAC}$ 회원국의 시민사회에 관한 입장 정립에 정책적 조언을 하였다. 자문그룹은 아크 라회의와 같은 원조대화의 장에서 $\mathrm{CSO}$ 의 목소리를 직접적으로 들을 수 있는 공간이 마련되어야 한 다고 제안하였다. 또한 아크라회의에서 파리선언을 보완하고 이를 실행할 때 시민사회의 관점과 역 할을 더욱 적극적으로 포함시켜야 한다는 입장을 보였다. $\mathrm{CSO}$ 에 관해서도 개발효과성을 제고하는 노력이 필요하다고 지적하면서, 정부나 원조기관이 $\mathrm{CSO}$ 개발효과성에 긍정적 영향을 주는 조건과 환경에 관한 이슈를 다루어야 한다고 촉구했다.

\section{Better Aid 조직, 주요활동, 재정지원 현황}

Better Aid는 1000 개 이상의 $\mathrm{CSO}$ 로 구성된 일종의 네트워크조직체이다. 다시 말해 조직의 정관과 이사회가 구성되어 있는 법적구성체라기보다는 활동의 유연성과 단체들의 민주적 참여 통로가 확보 될 수 있는 수평적 네트워크 조직을 지향하고 있다. 따라서 주요 의사결정은 한국의 KoFID를 포함한 31개 단체로 구성된 조정그룹(Better Aid Coordinating Group, BACG)에서 이루어진다. ${ }^{3)}$

Better Aid는 $\mathrm{OECD} / \mathrm{DAC}$ 원조효과성 작업반의 집행위원회에 세계시민사회의 대표자격으로 공식 적으로 참여하고 있다. 국제개발협력에서 권리에 기반한 개발효과성 제고를 주요 활동 목표로 삼고 있다. 정책문서, 회의참석, 로비, 시민사회 동원 등 다양한 방법을 통해 공정한 원조체계(Aid Architecture)를 위한 법적·제도적 개혁을 추진하고, $\mathrm{PD}$ 와 $\mathrm{AAA}$ 실행과 감시를 위한 국가별·주제별 협의과정을 추진하였다. 또한 HLF4 대응을 위한 국제시민사회 대응 결집체의 역할을 하고 있다.

3) 조정그룹의 공동의장은 Tony Tujan(IBON/ROA)과 Cecilia Alemany(AWID)가 맡고 있다, 조정그룹에 참여하고 있는 주 요 단체는 ActionAid, ACT International Network, Femnet, Afrodad, ANND, APWLD, AWID International, CCIC, Care Int'I, CIVICUS Int'I Networks, CONCORD, Eurodad, IBIS, IBON, InterAction, ITUC, KoFID, LDC Watch, Social Watch, TI, Uganda National NGO forum, WIDE, Zimcodd 등이 있다. 
Better Aid는 OECD/DAC과 제도적 협의채널을 다양하게 확보하고 있다. 아크라회의 이후 $\mathrm{BACG}$ 는 $\mathrm{OECD} / \mathrm{DAC}$ 원조효과작업반의 핵심결정기구인 집행위원회에 공식멤버로 참여하여 시민사회의 목 소리를 대변하고 있고, 또한 작업반 산하에 설치된 클러스터 A의 주인의식과 책무성(ownership and accountability) 위원회, 클러스터 B의 국가시스템(country system), 클러스터 C 진척평가위원회 (assessing progress)에 참여하고 있다. 특히 CSO 개발효과성과 이를 가능하게 하는 환경조성을 위 한 태스크팀의 핵심 멤버로 참여하고 있다. 최근에는 활동영역을 $\mathrm{OECD}$ 를 넘어 $\mathrm{UN}$ 개발협력포럼 (UNDCF), Rio20, G20등으로 확대하고 시민사회의 주장을 대변하고 있다.

특히 2011년 부산 개발원조총회에서 시민사회대표 300명의 공식 참가단을 선정하는 역할을 하고 있다. 이번 총회에는 164 개국에서 정부대표 3 인, 의회대표 1 인, 민간대표 1 인의 최소 5 명이 참가하여 총 1500-2000명 정도 참가단 규모를 예상하고 있는데 시민사회 대표 300명은 Better Aid의 주관하 에 별도의 프로세스로 선발되었다. 시민사회 대표 선발 기준은 개발협력분야의 전문지식과 이를 총 회준비과정과 총회 개최시에 기여할 수 있는 인사로 정하였다. 선발대상은 대륙별로 인원이 배정되 었고 또한 글로벌단위와 한국의 참여인사는 별도로 선발되었다. 직능별, 지역별, 국가별, 대륙별 참 여인사의 현황은 〈표-1〉과 같다. 여기서 주목할 점은 주최국인 한국의 경우는 전체인원의 $10 \%$ 인 30 명이 배정되었다는 것과 모든 선발단위에서 노동조합, 젠더, 농업 관련 시민사회 인사가 필수적으로 참여해야 한다는 것이다. ${ }^{4)}$

〈표-1〉HLF-4 시민사회 대표 참여 현황

\begin{tabular}{|c|c|c|c|c|c|c|c|c|}
\hline & 아프리카 & 아시아 & 중남미 & 중동 & EU/북미 & Global & 한국 & 전체 \\
\hline 지역 & 20 & 20 & 14 & 3 & 18 & \multirow{3}{*}{50} & \multirow{3}{*}{30} & \multirow{3}{*}{300} \\
\hline 국가 & 40 & 40 & 21 & 7 & 37 & & & \\
\hline 총인원 & 60 & 60 & 35 & 10 & 55 & & & \\
\hline 노동조합 & 4 & 4 & 2 & 1 & 4 & 3 & 2 & 20 \\
\hline 젠더 & 4 & 4 & 3 & 1 & 4 & 3 & 2 & 20 \\
\hline 농업 & 5 & 5 & 3 & 1 & 2 & 3 & 2 & 20 \\
\hline
\end{tabular}

\section{Better Aid의 정책입장}

Better Aid는 부산 개발원조총회의 전체의제와 회의 구성 요소(building block)에 관한 정책옹호활 동과 로비를 전개하고 있는데 주요 의제와 구성 요소에 관한 Better Aid의 정책주장은 다음의 네 가지 정책문서에서 가장 잘 나타나 있다: “개발협력에 관한 일반적 입장”(Development Cooperation: Not

4) CSO 참석자 총 300 명 중 100 명은 Donor Trust Fund(ADB)에서 참여비용을 지원하며, 나머지는 자비 혹은 Better Aid 차원의 CSO Fund를 통해서 지원할 예정이다. 
Just Aid, 2010년 1월), "개발효과성에 관한 입장"(Development Effectiveness in Development Cooperation-a Rights-based perspective, 2010년 10월), "개발협력 국제체계에 관한 입장"(Making development cooperation architecture just: governance principles and pillars, 2011년 3월), "HLF4관련 대응전략과 정책제안"(CSOs on the Road to Busan: Key Messages and Proposals, 2011년 3월). ${ }^{5)}$

\section{1) 국제개발협력의 9 개 쟁점}

Better Aid는 참여단체와 회원의 광범위한 의견수렴을 거쳐 작성되는데, 2010년 1월에 발표된 "개 발협력에 관한 일반적 입장”에서 현재 국제개발협력의 주요쟁점을 정리하고 있다. 일일 1.25 달러 미 만으로 생활하는 절대빈곤 인구가 14 억 명에 달하고, 국가 내 구성원간과 국가 간 불평등이 심화되고 있는 현실에서 선진국과 개도국 모두가 국제적으로 합의된 개발목표(IADGs), 파리선언(2005), 아크 라행동계획(2008) 이행이 실패하고 있다는 시각에서 총 9 개의 쟁점에 관해 다음과 같은 입장을 전개 한다. ${ }^{6)}$

\section{쟁점 1. 국제개발협력 개혁의 프레임워크로서 개발효과성 제고}

2005년 이후 국제개발협력에서 원조효과성 논의가 주요 국제규범으로 자리 잡고 있지만, 개발협 력 분야의 원조효과성이 개혁의 필수요소임에도 불구하고 공여국 중심의 기술적 측면이 강조되고 개 발협력 결과(impact)에 대한 논의가 부족하기 때문에 새로운 프레임워크인 '개발효과성'으로 확대 발 전되어야 한다는 주장이다. 개발효과성은 가난하고 소외된 사람들의 삶에 개발 행위자들의 행동이 미치는 영향에 주목하면서 이들이 개발의 주체이자 주인의 자리에 놓여야 한다고 본다. 이들의 실질 적인 삶의 개선을 위해 무역, 시장경제, 외국인직접투자와 부채를 포함한 모든 분야에서 국제적인 정 책 구조의 변화를 요구하고 있다. ${ }^{7)}$

\section{쟁점 2. 포괄적, 다자적, 공정한 원조 체계의 변혁}

$\mathrm{OECD} \mathrm{DAC}$ 중심의 개발원조체계는 선진공여국 중심의 제한된 멤버십으로 구성되어 있고, 배타적 인 권한을 행사하기 때문에 정당성과 지속가능성의 문제가 있다고 본다. 실제로 중요한 비공식 모임 에서 개도국의 참여는 불가능하고 쟁점형성과 정책결정과정에서 개발도상국의 개입이 어려운 현실이 다. 그렇기 때문에 원조체계의 개혁방향은 빈곤하고 소외된 개발도상국의 개발주체들이 참여할 수

5) Better Aid의 문건 작성은 우선 문건작성의 필요성을 BACG회의에서 결정하고, 소규모의 초안작성팀이 구성되어 일차 초안을 작성한다. 이후 BACG위원과 개별단체에 공개적인 회람과 의견수렴과정을 거쳐, 2차 초안이 만들어지고, 이를 $\mathrm{BACG}$ 회의에서 최종수정과 심의를 거쳐 확정되는 절차를 거친다.

6) Better Aid. 2010. Development Cooperation: Not Just Aid

7) '개발효과성'에 관해서는 개발효과성에 관한 입장(Development Effectiveness in Development Cooperation-a Rightsbased perspective, 2010년 10월)에서 더 자세히 논의될 것이다. 
있어야 하고, 국제적인 개발정책의 일관성이 담보되어야 한다. 특히 국제인권규약과 개발효과성, 연 대와 참여의 비전을 가지고 있는 원조체계가 되어야한다. ${ }^{8)}$

\section{쟁점 3. "(민주적) 주인의식" 국가 시스템, 조건성 정책 제한에 관한 현재 약속을 실행}

국가 주인의식에 대한 보다 민주적인 이해가 필요하고, 완전한 비구속성 원조를 실현하며, 다년간 예측가능한 개발원조를 약속해야 한다. 개발원조는 공여국이 아닌 파트너국에서 필요한 지원이 되어 야 한다. 개발원조의 경제적·정치적 조건 결부는 개도국의 민주적 주인의식 약화로 인한 정부의 책무 성 감소를 조장하는 우려가 있다. 제4차 HLF은 이러한 원칙 수행을 위한 정확한 시행일정을 약속해 야 한다.

\section{쟁점 4. 양성평등과 여성의 권리 추구}

현재의 원조효과성 구조에서는 양성평등 관점의 결여로 인해 여성의 취약함이 방치되어 있다. 이 미 아크라행동의제(AAA)는 양성평등과 인권존중, 환경의 지속가능성이 가난한 여성·남성과 아동의 삶과 잠재력에 지속가능한 영향을 줄 수 있는 초석이 된다고 밝힌바와 같이 모든 개발원조 정책은 양 성평등과 여성의 권리에 기반해 수립되어야 한다. 특히 여성인권단체에 대한 재정지원이 중요하며, 여성들이 그들 지역의 우선순위에 대한 독자적인 판단을 바탕으로 스스로 프로젝트를 기획하고 수행 할 수 있는 기회를 제공해야 하는 점을 강조하고 있다.

\section{쟁점 5. "제대로 된 일자리(decent work)와 형평성 있는 경제개발을 추진}

원조의존성을 극복하기 위해서 개발협력은 제대로 된 일자리와 생활을 확보할 수 있는 다양하고, 생산적이고, 자립적이며, 생태적으로 지속가능한 개발도상국 국내경제 구축의 기반을 마련해야 한 다. UN 경제이사회나 국제노동기구(ILO)의 노동 기준에 맞춰 사람이 중심이 되는 발전과 완전고용, 제대로 된 일자리 마련을 위해 무역과 재정정책에 대한 조정이 이루어져야 한다. 특히 세계경제의 위 기상황에서는 국가와 국제경제의 회복뿐만 아니라 빈곤하고 소외된 사람과 공동체의 필요에 부응하 는 정부정책이 수립되어야 한다.

8) 원조체계의 개혁에 대한 구체적인 7 가지 제안을 하고 있다. 1.남반구의 대표성을 강화해야 한다. 2. HLF-4를 준비하는 과정에서 원조작업반의 참여범위를 넘어서, 개발도상국을 포함하는 회의체(caucus)를 구성해야한다. 3. 부산회의 이후 원조작업반을 대체하기 위해 UNDCF와 같은 관련 UN기구와 조정협의를 해야 한다. 4. 개발도상국의 지역기구와 체계 적인 결합이 있어야 한다. 5. 의회와 시민사회의 원조효과성작업반 참여가 강화되어야 한다. 6. 원조체계개혁 협상에 시민사회의 국가, 지역, 글로벌 네트워크가 포함되어야한다. 7. 신흥공여국이 참여를 독려해야 한다. 


\section{쟁점 6. 민주적 주인의식과 참여를 가능하게 하는 환경(enabling environment) 조성}

$\mathrm{CSO}$ 는 의회와 언론, 기업과 함께 빈곤과 불평등 감소를 위해 사회적 정치적 경제적 변화를 가져 오는데 중요한 역할을 하고 있다. 이미 아크라행동계획에서 $\mathrm{CSO}$ 는 정부와 사적영역을 보완하는 독 립적인 개발 주체'로 인정되었으며 이를 위해 공여국들은 $\mathrm{CSO}$ 가 개발에 최대한 기여할 수 있도록 가 능하게 하는 환경을 제공하는 것을 약속하였다. Open Forum은 이러한 이슈에 대해 CSO의 논의를 확대하고 개발효과성을 위한 $\mathrm{CSO}$ 책무성 강화를 위해 조직되었다. 가난하고 소외된 사람들이 스스 로의 권리를 주장할 수 있도록 하는 역량강화가 필수적이며 이를 위해 법적인 프레임워크와 매커니 즘의 필요성을 강조하고 있다.

\section{쟁점 7. 원조와 개발효과성 평가 참여 범위 확대를 통해 개발결과에 대한 상호 책무성 제고}

파리선언의 5 대원칙 중의 하나인 상호책무성 이행은 심각하게 부진한 상황이다. 아크라행동계획 과 책무성에 관한 국제적인 검토가 이를 보완해 줄 것으로 기대되지만, 국가별 검토에서 다양한 개발 주체의 참여 기회가 보장되고 있지 않다. 글로벌차원의 모니터링도 다자적이고, 개방되어야 할뿐 아 니라 풀뿌리차원의 참여가 보장되어야 한다. 제 4 차 $\mathrm{HLF}$ 은 아크라행동계획에서 밝힌바와 같이 모니 터링에서 의회와 시민의 참여 중요성을 이어가야 한다.

\section{쟁점 8. 원조효과성과 공여국/수원국 정부의 책무성을 제고하기 위한 투명성 강화}

Better Aid는 아크라행동계획 제 $24,25,26$ 항에서 강조된 보다 확대된 투명성과 책무성 약속에 주 목한다. 이는 원조재정, 예산, 지출, 조달, 감사와 원조집행에 관련된 조건들을 모두 시민에게 공개 하는 것을 포함하고 있다. 개발도상국에게 원조 중기계획을 밝히는 것도 약속되었지만 이는 이루어 지지 않고 있다. 특히 아크라회의에서 출범한 국제원조투명성구상(International Aid Transparency Initiative, IATI)에 모든 공여국이 참여할 것을 촉구한다. 반면 개발도상국 정부도 원조가 어디서 오 고, 어떻게 쓰여지고, 평가되는지를 의회·시민단체와 언론 등에 투명하게 공개해야 한다.

\section{쟁점 9. 개발에 영향을 주는 정책의 전반적 개혁을 통한 빈곤과 불평등 감소}

원조가 빈곤과 불평등을 감소시키고 가난하고 소외된 사람들의 권리를 증진시키기 위해서는 대규 모 자금유출, 불공정하고 불투명한 무역과 투자레짐, 조세회피로부터 개발도상국을 보호할 수 있는 정책 환경이 조성되어야 한다. 하지만 불행히도 현재 IMF, 세계은행, WTO 같은 현재의 세계적 경제 기구들이 무책임한 시장과 금융자유화를 추진하고 개도국 국내정책을 제한하고 있다. 현재 중첩적인 경제위기는 단순히 원조체계의 개혁뿐만 아니라 글로벌 무역, 투자, 금융 체계의 개혁과 국내 개발정 책의 변화를 요구하고 있다. 국제 금융과 무역레짐이 보다 포용적이고, 참여적이며 빈곤층에 민주적 
으로 책임을 다 할 수 있는 기구로 거듭나야 한다. 도하 무역라운드와 기후변화 관련 협상 등에서도 국제개발 목표가 반드시 중심이 되어야하고 빈곤국의 부담을 덜어주는 방식으로 진행되어야 한다.

\section{2) 개발효과성과 원조체계 개혁}

지금까지 제안된 부산 개발원조총회 의제 중에 개발효과성과 원조체계는 가장 많은 관심을 모으고 있다. 따라서 이 두 가지 주제에 관한 Better Aid의 입장을 좀 더 자세히 살펴보고자 한다.

개발효과성에 대한 정의는 현재까지 서로 다른 주체들에 의해 다양한 시각이 존재한다. 그동안 개 발효과성이란 용어는 원조 효과성 개념과 혼재되어 사용된 경우가 많았다. 그 정의 역시 상황에 따라 다르게 내려졌는데, 지난 2009년 9월 The North-South Institute의 보고서 "Development Effectiveness: Toward New Understandings"에서 세넌 킨도네이(Shannon Kindornay)와 빌 모턴 (Bill Morton)는 각각의 개발 주체에 따라 4가지 관점으로 구분하여 제시하였다. 각 관점은 배타적이 라기보다는 유기적 관계를 유지하고 있다.

첫 번째, 개발효과성은 조직의 효과성(Development Effectiveness as Organizational Effectiveness) 으로 정의할 수 있다. 세계은행과 같은 다자원조기관들은 내부 정책과 프로그램 이행 등 정해진 목표에 대해 조직이 얼마나 효과적으로 달성했는지 평가의 수단으로 개발 효과성의 개념을 사용하였다. 주로 프 로그램 평가에 초점을 맞추어 공여기관의 조직적 성과와 결과의 효과성을 의미하는 바로 사용되었다.

두 번째, 정책의 일관성 혹은 조화(Development Effectiveness as Coherence or Coordination) 로 정의할 수 있다. 원조기관, 특히 양자 기관들은 개발에 영향을 미치는 요소로 원조만이 해결책이 아님을 인식하고, 정책일관성을 통해 무역, 안보, 이민 등과 같은 비원조정책들이 개발과정에 미치는 영향이라 정의한다. 정부의 수직적 조직형태, 부처간의 경쟁의식, 정책우선순위에 대한 의견 차이는 수평적 조화와 정책 일관성을 달성하는데 제약이 되기도 한다.

세 번째, 원조를 통한 개발성과(As the development outcomes from aid)로 정의된다. 이는 주로 시민사회단체(CSO)에서 바라보는 관점으로, 정책이나 원조 방법에 대한 효율성보다는 원조를 통한 실질적인 개발결과로 고려된다. 원조와 개발효과성을 배타적 관계로 보는 것이 아닌 상호보완적 관 계로 보며, 인권, 민주주의, 무역, 재정과 투자 등 다양한 요소를 아우른다. 현재, 원조효과성에 대한 국한된 공여국 중심의 의제를 조정해야하고 개발효과성의 패러다임 전환이 필요하다. 이는 인권, 사 회정의, 양성평등, 지속 가능한 개발, 환경, 민주주의적 주인의식을 포괄하는 새로운 원조체계로의 논의가 발전하여야 한다고 말한다.

네 번째, 총체적인 개발성과(Development Effectiveness as Overall Development Outcomes)로 서 개발효과성이다. 이는 원조 성과에 대해 제한을 두지 않는, 비 원조 부문을 모두 포함한 개발요소 의 총체적인 영향평가라고 볼 수 있다. 이전 3 가지 관점을 포함한 포괄적 접근방식이다. DFID의 보 고서에서 개발결과는 특정 소수의 활동이 아니라 다양한 요소와 행위자들에 의해 나타나기 때문에 개발 과정의 책임이 모든 개발 파트너들에게 있다고 보며 자체 프로그램 효과성과 개발효과성을 구 
분하고 있다. UNDP는 삶속에서 지속적 변화를 만들어내는 개발의 충족 요소와 조건들이 개발효과성 임을 시사했다. 이는 개발효과성에 대한 $\mathrm{CSO}$ 들의 관점과 범정부적 접근방식, 정책일관성을 반영하 는 복합적인 관점이다. ${ }^{9)}$

Better Aid의 입장은 위의 세 번째 부류에 해당된다고 볼 수 있는데, 2010년 10월에 발표된 〈개발 효과성에 관한 입장>(Development Effectiveness in Development Cooperation-a Rights-based perspective)에서 보다 구체적으로 드러나고 있다. 기존의 개발모델은 평등한 성장과 광범위한 사회 진보에 기여하지 못하고, 워싱턴 컨센서스에 입각한 자유시장주의, 민영화, 규제완화와 긴축재정, 노 동시장의 유연화는 기존의 개발모델의 불완전성을 노출시키고 있다는 시각에서 출발한다. 개발이 모 두를 위해 개선된 삶임에도 불구하고, 현재 경험하고 있는 현상은 국가 내·국가 간의 심화되는 불평 등, 가난한 이들의 권리와 사회적 보호 악화, 개발도상국 천연자원의 급속한 고갈이다. 따라서 이러 한 위기는 현재의 접근법이 구조적인 문제점을 가지고 있음을 증명하며, 근본적인 변화의 필요성과 시급성을 보여준다고 판단되며, 시민사회단체에서는 기본적 정의의 가치, 원칙에 기반한 개발모델을 요구한다.

또한 기존의 글로벌 거버넌스와 국제 협력 시스템은 세계가 직면하고 있는 주요 개발도전과 의제를 대응함에 있어 일관적이고 효과적인 방법으로 해결하겠다는 정치적 의지가 부족하다. 이는 새천년개 발목표를 포함한 국제적으로 합의된 개발목표를 성취하고 파리선언과 아크라행동계획에서 이뤄진 약 속을 이행하는 과정에서도 드러난다. 개발도상국이 자신의 개발을 구상하는 정책적 자유를 무시당하 는 가운데에 국제 원조, 무역, 채무, 재정과 투자체계 등이 심각한 권력 불균형에 시달리고 있다.

현재의 국제 개발 협력 시스템만의 힘으로는 점차 늘어나는 세계의 요구를 충족시킬 수 없다. 2009년 공적 개발원조는 경제개발협력기구 개발원조위원회의 공여국 GNI의 0.31\%만을 차지하고 있 다. 우리가 $\mathrm{MDG}$ 와 IADG를 포함하는 국제개발목표를 성취하기 위해서는 $\mathrm{DAC}$ 국가들뿐만 아니라 $\mathrm{DAC}$ 국가가 아닌 다른 국가들의 원조도 덧붙여 나머지 $99.7 \%$ 의 경제활동이 개발 효과성에 이바지하 도록 해야 한다. 개발효과성은 곧 빈곤퇴치와 성평등, 모두를 위한 양질의 일자리, 환경 지속성, 개 발과정에서의 빈곤하고 소외된 사회계층의 중심적인 역할을 확보하는 것을 의미한다. 특히, 더 나은 원조는 원조의 효과성보다 개발의 효과성에 집중하는 개발협력에 대한 새로운 접근방식을 요구한다. Better Aid는 세계 개발 체계의 근본적인 개혁을 지지하면서 새로운 국제개발협력체계에 대해 포용 적이고, 인권을 기반으로 하며, 민주주의적인 것을 추구해야 하며, 자주성과 일관성을 향상시켜야 한 다고 주장하고 있다.

Better Aid가 2011년 3월에 발표한 〈개발협력 국제체계에 관한 입장〉(Making development cooperation architecture just: governance principles and pillars)에 따르면 새로운 국제개발협력 체계는 다음의 원칙을 바탕으로 개혁되어야 한다. ${ }^{10)}$

9) Shannon Kindornay and Bill Morton, Development Effectiveness: towards new understandings, Issues Brief Development Cooperation Series September 2009, The North-South Institute 
첫째, 인권, 빈곤 감소, 성평등, 사회 정의, 양질의 일자리와 환경 지속가능성에 집중한다.

둘째, 국가 고유의, 그리고 민주주의적으로 채택된 개발 정책이 계획되어야 한다.

셋째, 국가 간 권력 불균형을 바로잡아야 한다. (예: 상호 책무성, 구속성 원조 폐지, 공여국이 제 시하는 정책 조건 교정, 원조 투명성과 예측가능성 증대, 다수 이해관계자의 참여)

넷째, 국제 원조, 무역, 투자와 금융 등 상호 협력적인 정책을 추구하여 개발권리실현을 지지하고 발전시킨다.

다섯째, 국제적 합의와 회의에서 이뤼진 공약에 서명한 국가들이 보장하는 메커니즘을 포함하여 인권에 기반한 국제 기준 체계를 바탕으로 해야 한다.

여섯째, 시민 사회 단체(특히 여성단체, 사회적 파트너와 풀뿌리단체)가 새로운 개발 체계에서 정 부와 다른 개발 참여자들과 함께 공식적인 형태로 정식 구성원으로 인정되어야 한다.

\section{3) 부산 개발원조총회 대응 전략과 정책제안}

지금까지 논의된 국제개발협력 주요이슈와 부산 개발원조총회 의제에 관한 Better Aid의 정책입 장을 재검토하고 부산회의 대응전략과 정책제안을 마련하기 위해 2011년 3월 스웨덴 하노샌드에서 Open Forum과 함께 합동 전략회의를 개최하였다. 이 회의에서 Better Aid는 Open Forum과 함께 〈HLF4관련 대응전략과 정책제안〉 (CSOs on the Road to Busan: Key Messages and Proposals)을 채택하였다. 이 문건에서는 네 가지 정책목표를 설정하고, 각 목표는 각각 실행전략을 제시하고 있 다. 2011년 11월 부산회의 개최까지 OECD/DAC 원조효과성작업반 회의를 비롯한 다양한 국제회의에 서 아래 전략이 추진될 예정이고, 또한 개별 공여국가를 상대로 정책옹호활동을 전개하고 있다. 주요 내용은 아래와 같다. ${ }^{11)}$

10) Better Aid. 2011. Making development cooperation architecture just: governance principles and pillars

11) Better Aid. 2011. CSOs on the Road to Busan: Key Messages and Proposals

A. Fully evaluate and deepen the Paris and Accra commitments through reforms based on democratic ownershipa. a. Redress the failure to make progress on Paris and Accra commitments. b. Carry forward and strengthen the Paris and Accra commitments through realizing democratic ownership in development cooperation. c. Implement full transparency as the basis for strengthened accountability and good governance.

B. Strengthen development effectiveness through development cooperation practices that promote human rights standards and focus on the eradication of the causes of poverty and inequality. a. Commit to and implement rights-based approaches to development. b. Promote and implement gender equality and women's rights c. Implement the Decent Work Agenda as the cornerstone for socially inclusive and sustainable development strategies.

C. Affirm and ensure the participation of the full diversity of CSOs as independent development actors in their own right. a. Endorse the Istanbul Principles and acknowledge the Open Forum's International Framework for CSO Development Effectiveness to put these Principles into practice. b. Agree on minimum standards for government and donor policies, laws, regulations and practices that create an enabling environment for CSOs.

D. Promote equitable and just development cooperation architecture a. Launch an inclusive Busan Compact at HLF4, which brings together specific time-bound commitments and initiates fundamental reforms in the 
A. 민주적 주인의식에 기초한 개혁을 통하여 파리선언과 아크라 행동계획의 전적인 이행 평가 및 심화
a. 파리선언과 아크라 행동계획의 진척 실패 문제 제기
b. 개발협력의 민주적 주인의식 실현을 통하여 파리선언과 아크라 행동계획을 강화 및 이행 c. 책무성 및 좋은 거버넌스를 강화시키는 기반으로서의 투명성 이행

B. 빈곤의 원인과 불평등 퇴치 및 인권 기준을 촉진하는 개발협력실천을 통하여 개발효과성 강화
a. 인권에 기반한 개발을 실천을 위한 서약 및 이행
b. 성평등 및 여성의 권리 촉진 및 이행
c. 사회적 포용 및 지속가능한 개발 전략의 주춧돌로서 적합한 일자리 제공, 아젠다를 이행

C. 고유 권한을 가진 독립된 개발주체로서의 다양한 $\mathrm{CSO}$ 의 전적인 참여 보장

a. CSO 개발효과성 증진을 위한 이스탄불 원칙의 승인 및 채택

b. CSO 개발효과성을 가능하게 하는 환경을 조성하는 정부 및 공여기관의 정책, 법률, 규제 및 방법에 대한 최소한의 기준 동의

D. 공평하고 정의로운 개발협력 구조 촉진

a. 부산세계개발원조총회에서 포용적 부산협약(Busan Compact)을 착수-서약 준수 시한을 규정하고 개발협력의 글로벌 거버넌스에 대한 근본적 개혁을 주도할 수 있어야 함

b. 정책 대화 및 기준 수립을 위한 공평하고 포용적인 다자간 포럼 구성

\section{Open Forum의 활동현황과 대응전략}

\section{1. 일반현황}

CSO개발효과성을 위한 오픈 포럼(Open Forum for CSO Development Effectiveness, Open Forum) 은 정부와 공여기간의 원조효과성 논의를 넘어 전세계 $\mathrm{CSO}$ 고유의 개발사업에 대한 개발효과성 증진 을 위해 기본 틀(framework)을 만들고, 이를 실행하기 위해 2008년 아크라회의 직후에 구성되었다. 이미 이러한 포럼의 필요성은 2007년 1월 $\mathrm{OECD} / \mathrm{DAC}$ 내에 설치된 시민사회 자문그룹(AG-CS)이 개 발과 시민사회관련 포럼을 개최하고 그 개최를 $\mathrm{OECD}$ 프로세스에 공식적으로 반영시키면서 제기되

global governance of development cooperation. b. Create an equitable and inclusive multilateral forum for policy dialogue and standard setting. 
었다. 2008년 2월 캐나다 오타와에서 개최된 자문그룹회의에서 시민사회 고유의 개발효과성 증진을 위한 기본틀을 만들기로 결정하고, 2008년 6월 파리에서 70여개의 $\mathrm{CSO}$ 가 모여 $\mathrm{CSO}$ 개발효과성 증 진을 위한 Open Forum을 구성하기로 합의하였다. 이 회의에서 추진과정에서 개발성 확보, 시민사 회단체 개발효과성 비전수립, 공통의 원칙수립, 원칙 실행을 위한 가이드라인 합의, HLF4에서 가능 케 하는 환경의 최소 국제적 기준 합의의 다섯 가지 목표를 채택하였다.

Open Forum은 2011년 6월까지 74개국의 약 2000여개 CSO가 참여하고 있는데 주요 의사결정과 운영은 글로벌운영그룹(Global Facilitating Group, GFG)에서 이루어 진다. 이 운영그룹에는 현재 대륙별, 국제CSO네트워크, 여성단체, 지역주관단체 등의 35 개 단체가 참여하고 있고, 한국에서도 $\mathrm{KoFID}$ 가 중국, 일본, 캄보디아, 필리핀과 함께 아시아 대표로 활동하고 있다. 현재 Concord가 2011 년 2월까지 한시적으로 사무국을 맡고 있으며, 운영 재원은 Better Aid와 함께 영국, 스웨덴, 캐나다 등의 공여국으로부터 공동으로 지원받고 있다. Better Aid와의 관계는 아크라회의 이후 원조/개발효 과성 논의에서 시민사회 파트너로 협력하고 있으며, 2011년 4월에는 스웨덴 하노샌드에서 Better Aid와 공동 전략회의를(Hanosand Joint Strategy Meeting)를 개최하고 부산총회에 공동입장을 취 하고 있다.

〈그림 1〉Open Form 프로세스 개요

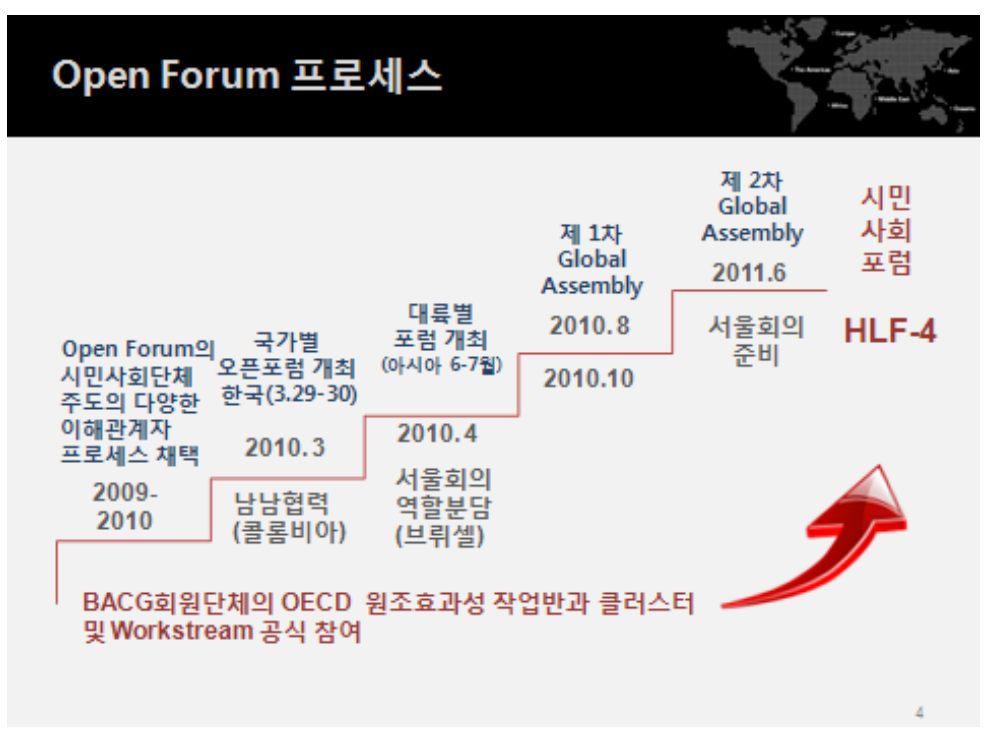

\section{Open Forum 프로세스: 국가, 지역, 테마, 글로별 협의 과정}

2009년 말부터 2011년 6월까지 74개국에서 2000여개 CSO가 참여하는 국가별 오픈포럼이 개최되 었다. 국가별 오픈 포럼에서는 $\mathrm{CSO}$ 개발효과성을 위한 원칙과 가이드라인에 대해 국가의 특수성을 
고려해 논의하였으며, 이는 다시 5 개 대륙에서 9 회의 지역별 워크샵에서 수렴되는 과정을 거쳤다. 시민사회의 개발협력 담론형성의 역사 중 글로벌한 차원의 합의가 국가, 지역으로부터 수렴되는 최 초의 민주적 절차를 밟은 과정이었다. 뿐만 아니라 국가, 지역별 워크샵과 함께 분쟁지역에서의 시민 사회 개발활동, 소외된 그룹과 $\mathrm{CSO}$, 노동조합, 젠더들의 테마별 워크샵도 전대륙을 걸쳐 8회가 개최 되었다. 이러한 논의는 2010년 6월 이스탄불에서 제1차 세계총회(Global Assembly)에서 아래와 같 은 “CSO 개발효과성을 위한 원칙"을 채택하는데 결정적인 기반을 제공하였다. ${ }^{12)}$

1. 인권과 사회적 정의의 존중과 증진

(Respect and promote human rights and social justice)

2. 여성과 여아의 권리를 증진하면서, 젠더 평등과 형평성 구현

(Embody gender equality and equity while promoting women and girls' rights)

3. 주민(people)의 주체적 역량제고, 민주적 오너십과 참여

(Focus on people's empowerment, democratic ownership and participation)

4. 환경의 지속가능성 증진(Promote environmental sustainability)

5. 투명성과 책무성 실행(Practice Transparency and accountability)

6. 공정한 파트너십과 연대 추구(Pursue equitable partnerships and solidarity)

7. 지식을 창출하고 공유하며, 상호학습 추진

(Create and share knowledge and commit to mutual learning)

8. 긍정적이고 지속가능한 변화를 실현하기 위해 약속

(Commit to realizing positive sustainable change)

이스탄불 원칙 실행을 위한 가이드라인, $\mathrm{CSO}$ 의 책무성 강화, 가능하게 하는 환경을 주요 내용으로 시엠립 컨센서스(Siem Reap Consensus on the International Framework for CSO Development Effectiveness, Siem Reap Consensus)가 2011년 6월 Open Forum 제2차 세계총회에서 채택되었 다. 시엡립 컨센서스는 이스탄불 원칙과 함께, 오는 부산총회에서도 개별공여국과 공여기관의 공식 적인 인정을 요청하고 그와 관련한 문건을 제출할 예정이다.

그러나 초기에 계획된 원칙실행을 위한 가이드라인설정, 지표개발, $\mathrm{CSO}$ 실행 검증방법제시 등의 포괄적인 목표에는 도달하지 못하였다. 또한, 이스탄불 원칙을 적용하는데 있어서 각 지역과 국가의 상황, $\mathrm{CSO}$ 의 역량, 개발 역할 등을 고려해야 한다는 점이 강조되면서 보편적인 지표와 실행검증방법 을 제시하기 보다는 정책옹호(advocacy)와 실행의 참고문건(toolkit)을 개발하는 것으로 합의되었다. $\mathrm{CSO}$ 가 개발협력과 관련해 그 잠재력을 최대한 발휘할 수 있도록 정부가 제공해야 하는 법적·제도적

12) Open Forum. 2010. Istanble CSO Development Effectiveness Principles 
환경 조성을 위해서도 개별국가의 문제점을 파악하고 국가별 상황에 맞는 개선결과를 가져오기 위해 Open Forum차원에서 개별 국가내의 정책옹호의 효과적인 방법을 개발하고 있다.

Open Forum은 국제개발협력에서 $\mathrm{CSO}$ 의 정책옹호활동이 주로 공여기관의 정책과 개발담론을 비 판하고 대안을 제시하는데 초점을 두고 있는데 반해, 개발효과성의 문제를 $\mathrm{CSO}$ 의 자기문제로 인식 하고 내부에서 책무성을 강화하는 논의를 시작했다는 점에서 긍정적으로 평가할 수 있다. 또한 논의 진행의 과정에서 개별국가단위, 지역, 테마, 글로벌 단위까지의 의견수렴 과정이 민주적 절차성을 확 보했다는 점에서 향후 세계시민사회의 활동방식에 새로운 계기를 마련했다고 볼 수 있다. 그러나, 부 산총회 이후의 장래는 매우 불투명한 상황에 놓여있다. 공여국의 재정지원이 부산총회까지로 한정되 어 있고 지금까지 사무국을 담당했던 Concord도 이사회결정에 의해 2012년 2월까지 사무국 파견인 원을 철수할 예정이다. 따라서 부산총회 이후의 $\mathrm{CSO}$ 개발효과성과 책무성 담보를 위한 시민사회 논 의구조가 어떻게 진행될 것인지 지켜봐야 하는 상황이다. 그러나 몇몇 국가별 시민사회연대체 (national platform)나 대부분의 참여단체들이 Open Forum의 존속 필요성에 공감하고 있기 때문에 이번 부산총회에서 Open Forum의 미래에 대한 긍정적인 합의가 이루어 질 것으로 예상된다.

\section{N. 맺으며}

Better Aid나 Open Forum 등이 부산총회 대응을 국제적 차원에서 전개하는 것에 조응하여, 한국 시민사회는 부산총회에 적극 대응하고, 개발NGO와 인권, 여성 등의 시민사회단체의 교류와 연대를 위해 2010년 9월 29일 '국제개발협력 한국시민사회포럼'(KoFID: Korea Civil Society Forum on International Development Cooperation)을 조직하였다. ${ }^{13)}$ KoFID는 두차례에 걸쳐 Open Forum 워크샵을 개최하여 $\mathrm{CSO}$ 개발효과성 논의를 이끌고 있고, 부산 개발컴팩트 수립을 위해 한국정부에 정책제안을 제시하고, Better Aid의 BACG와 Open Forum의 GFG에 대표를 파견하여 한국 시민사회 의 입장을 대변하고 있다. 또한 이를 계기로 한국 정부의 개발협력 정책 수립과 실행을 모니터하고 정책개선 권고 및 대안제시를 통해 시민사회와 사회적 약자의 목소리가 반영될 수 있도록 노력하고 있다.

2011년 8월에는 〈부산 세계개발원조총회(HLF-4)에 대한 국제개발협력시민사회포럼(KoFID)의 입 장과 정책 제언>을 작성하여 발표하였는데, 부산총회 준비와 이행원칙, 파리선언 평가와 원조개혁, 부산총회의 의제와 정책방향, 원조와 개발효과성, 개발을 위한 정책일관성, 상호책무성과 개발영향

13) 한국 국제개발협력학회, 굿네이버스, 기후변화연구소, 세이브더칠드런, 아시안브릿지, 아시아재단, 앰네스티코리아, 어린이재단, 월드비전한국, 월드투게더, 유엔인권정책센터, 인구보건복지협회 지구촌나눔운동, 참여연대, 코피온, 하 트하트재단, 한국여성단체연합, 한마음한몸운동본부, 한국에이즈퇴치연맹, 한국인권재단, 한국YMCA전국연맹, 한국 해외원조단체협의회, ODA Watch 
평가, 시민사회와의 파트너십, 포괄적 글로벌 개발협력체계, 부산 글로벌개발컴팩, 포스트 부산 프레 임워크에 대한 입장을 담고 있다. ${ }^{14)}$ 특히 한국정부에 대한 10 개 요구사항을 정리하여 정부에 전달하 였는데 그 내용은 다음과 같다.

1. 한국 정부는 부산총회에서 '원조를 넘어서 개발효과성'을 달성하기 위한 포괄적이고 실질적인 '새로운 글로벌 개발 컴팩'을 채택하여 개발협력의 질과 성과를 획기적으로 제고할 수 있도록 노력하여야 한다.

2. 한국정부는 개발효과성 의제가 결과적으로 $\mathrm{ODA}$ 의 축소와 민간재원으로의 대체가 아닌 글로벌 공공재로서 ODA가 더욱 확대되고 모든 개발재원이 지구촌 빈곤과 개발격차 해소에 우선적으로 사용될 수 있도록 노력하여야 한다.

3. 한국정부는 우리나라의 개발원조가 최빈국과 취약국 및 저소득국가의 MDGs 달성을 위해 우선 사용될 수 있도록 중점협력국과 지원분야 등 우선순위를 재점검하여야 한다.

4. 한국정부는 부산총회의 준비과정에서부터 모든 주요의제의 협상과정에 한국 시민사회의 의견 을 적극 반영하고 부산총회가 포괄적이고 민주적인 협력의 장이 되도록 노력하여야 한다.

5. 한국정부는 원조의 질적 제고를 위해 파리선언의 5 대 원칙을 지속적으로 이행하고 개발협력의 투 명성 제고와 성과관리, 분절화 방지와 책무성 증대를 위한 원조개혁 노력을 가속화하여야 한다.

6. 한국정부는 지구촌 극빈층의 빈곤탈출과 역량구축에 정책 우선순위를 두고 무역, 직접투자, 인 프라 건설과 농업, 환경, 이민과 노동정책 등에서 개발효과성을 달성하기 위한 정책일관성을 확보하여야 한다.

7. 한국정부는 부산총회에서 개발효과성을 측정, 모니터링, 평가 관리하기 위한 개발효과성 지표 를 개발하도록 하고, 인권에 기반한 접근방법 및 개발영향평가제도를 적극 도입하여 모든 개발 협력사업에 인권과 젠더, 환경기준을 적용함으로써 개발효과성을 제고해야 한다.

8. 한국정부는 시민사회의 개발효과성을 증진하기 위해 세계 시민사회가 합의한 이스탄불 원칙이 부산총회 결과문건을 통해 공식화되도록 노력하여야 한다.

9. 한국정부는 부산총회가 $\mathrm{OECD} / \mathrm{DAC}$ 를 넘어서 다양한 Non-DAC 개발원조 제공자들과 $\mathrm{G} 20$, 유 엔, 다자은행, 시민사회를 포함하는 미래지향적 개발 파트너십과 글로벌 거버넌스 체계를 만드 는데 적극 기여하도록 하여야 한다.

10. 한국정부는 부산총회가 한국 $\mathrm{ODA}$ 의 질적 수준 제고와 효과성 증진 및 통합적 원조시스템 마 련을 위한 중대한 계기가 되도록 후속조치를 마련하고 시민사회와 협력하여 포스트 부산 및 포스트 MDGs 체제를 적극 준비하여야 한다.

14) KoFID(한국국제개발협력 시민사회단체포럼). 2011. "부산 세계개발원조총회(HLF4)에 대한 입장과 정책제언" 
부산 세계개발원조총회는 2005년 파리선언과 2008년 아크라행동계획 이후 국제사회의 개발협력 노력과 성과를 평가하고 향후 보다 효과적인 원조규범과 체계를 마련할 수 있는 주요한 논의의 장이 다. 개발현장에서 빈곤하고 소외된 사람의 삶의 실질적 변화를 가져올 수 있기를 바라지만 개발협력 의 도전과제는 부산총회 이후에도 계속 지속될 것으로 본다. Better Aid와 Open Forum과 같은 세계 시민사회 네트워크는 아마도 OECD중심의 개발협력 체계에 대한 비판적 성찰을 통해 UN, G20, 국 제개발기구 등으로 활동대상을 넓혀갈 것이다. 한국시민사회도 부산총회라는 역사적 계기를 통해 국 제개발협력 담론형성과 정책개혁에 참여함과 동시에 한국국민의 개발협력에 관한 인식을 제고하고, 개발역량 강화와 책무성 제고라는 과제를 동시에 가지고 있다. OECD DAC에 가입한지 채 2년도 되 지 않는 국가이지만 한국정부가 다른 공여국과 달리 경제위기에도 불구하고 ODA증액 계획을 발표하 고 적극적으로 국제적인 개발협력 정책결정과 참여하고 있는 상황을 긍정적으로 판단하며, 향후 정 부-시민사회 파트너십을 통해 개도국 빈곤계층의 실질적 삶의 변화에 기여하는 개발협력 정책 수립 과 집행을 기대해 본다. 


\section{참고문헌}

\section{1. 국내문헌}

김혜경. 2009. “국제시민사회의 이슈와 한국시민사회의 대응과제” 제 5 회 ODA Watch 지구촌포 럼 자료

손혁상 외. 2011.「개발효과성 제고를 위한 정부-시민사회 협력방안 연구」. KOICA 연구보고 서. 한국국제협력단 (출판 예정)

한국국제개발협력 시민사회단체포럼(KoFID). 2011. "부산세계개발원조총회(HLF4)에 대한 입 장과 정책제언.” 정책문서

한재광. 2010. “지구촌 빈곤감축을 위한 시민사회의 노력”「국제개발협력」제4호

\section{2. 국외문헌}

Bebbington, Anthony, Sam Hickey, and Diana Miltin. eds. 2008. Can NGOs Make a Difference? The Challenge of Development Alternatives. London: Zed Books

Better Aid(ISG). 2009. Better Aid: A Civil Society Position Paper for the 2008 Accra High Level Forum on Aid Effectiveness. Better Aid Position Paper

Better Aid. 2010. Development Effectiveness in Development Cooperation: a Rights-based perspectives.

Better Aid Position Paper

Better Aid. 2010. Development Cooperation: Not Just Aid. Better Aid Position Paper

Better Aid. 2011. Making development cooperation architecture just: governance principles and pillars.

Better Aid Position Paper

Better Aid. 2011. CSOs on the Road to Busan: Key Messages and Proposals.

Lewis, David \& Nazneen Kanji. 2009. Non-Governmental Organizations and Development. Routledge Open Forum. 2011. Siem Reap Consensus: International Framework for CSO Development Effectiveness. Open Forum for CSO Development Effectiveness

Open Forum. 2010. Istanbul CSO Development Effectiveness Principles. Open Forum for CSO Development Effectiveness

Shannon Kindomay and Bill Morton. 2009 "Development effectiveness: Towards new understanding" Issues Brief Development Cooperation Series, The North-South Institute 